Article

\title{
Interoperability between Building Information Modelling (BIM) and Building Energy Model (BEM)
}

\author{
Gabriela Bastos Porsani (D), Kattalin Del Valle de Lersundi (D), Ana Sánchez-Ostiz Gutiérrez (D) and \\ Carlos Fernández Bandera * (D)
}

School of Architecture, University of Navarra, 31009 Pamplona, Spain; gbastospors@alumni.unav.es (G.B.P.); kdelvalle@unav.es (K.D.V.d.L.); aostiz@unav.es (A.S.-O.G.)

* Correspondence: cfbandera@unav.es; Tel.: +34-948-425-600 (ext. 803189)

Citation: Bastos Porsani, G.; Del Valle de Lersundi, K.; Sánchez-Ostiz Gutiérrez, A.; Fernández Bandera, C. Interoperability between Building Information Modelling (BIM) and Building Energy Model (BEM). Appl. Sci. 2021, 11, 2167. https://doi.org/ 10.3390/app11052167/

Academic Editor: Elmira Jamei

Received: 31 January 2021

Accepted: 23 February 2021

Published: 1 March 2021

Publisher's Note: MDPI stays neutral with regard to jurisdictional claims in published maps and institutional affiliations.

Copyright: (c) 2021 by the authors. Licensee MDPI, Basel, Switzerland. This article is an open access article distributed under the terms and conditions of the Creative Commons Attribution (CC BY) license (https:/ / creativecommons.org/licenses/by/ $4.0 /)$.

\begin{abstract}
Building information modelling (BIM) is the first step towards the implementation of the industrial revolution 4.0, in which virtual reality and digital twins are key elements. At present, buildings are responsible for $40 \%$ of the energy consumption in Europe and, so, there is a growing interest in reducing their energy use. In this context, proper interoperability between BIM and building energy model (BEM) is paramount for integrating the digital world into the construction sector and, therefore, increasing competitiveness by saving costs. This paper evaluates whether there is an automated or semi-automated BIM to BEM workflow that could improve the building design process. For this purpose, a residential building and a warehouse are constructed using the same BIM authoring tool (Revit), where two open schemas were used: green building extensible markup language (gbXML) and industry foundation classes (IFC). These transfer files were imported into software compatible with the EnergyPlus engine-Design Builder, Open Studio, and CYPETHERM $\mathrm{HE}$-in which simulations were performed. Our results showed that the energy models were built up to $7.50 \%$ smaller than in the BIM and with missing elements in their thermal envelope. Nevertheless, the materials were properly transferred to gbXML and IFC formats. Moreover, the simulation results revealed a huge difference in values between the models generated by the open schemas, in the range of 6 to 900 times. Overall, we conclude that there exists a semi-automated workflow from BIM to BEM which does not work well for big and complex buildings, as they present major problems when creating the energy model. Furthermore, most of the issues encountered in BEM were errors in the transfer of BIM data to gbXML and IFC files. Therefore, we emphasise the need to improve compatibility between BIM and model exchange formats by their developers, in order to promote BIM-BEM interoperability.
\end{abstract}

Keywords: building information modelling (BIM); building energy model (BEM); green building extensible markup language (gbXML); industry foundation classes (IFC); interoperability; digital twin; sustainable construction; intelligent buildings assessment; sustainability performance; simulation tools for building

\section{Introduction}

The challenge of designing a high-performance building demands better data exchange between the building information modelling (BIM) and building energy model (BEM). The building sector is responsible for $40 \%$ of the energy consumption in Europe, in which the building envelope is the main constructive element, in terms of its impact on the building's energy consumption [1]. The European Union has submitted a set of directives to eliminate inefficient buildings, through the Energy Performance of Buildings Directive (EPBD) [2,3], which is the leading legislative and policy instrument. This directive focuses on the building sector (i.e., new and existing constructions) and determines that the existing ones must be nearly zero energy buildings (NZEBs) by 2050 [4]. The NZEB standard is valuable for the environment, as well as for the end-users of the building, as 
energy savings also reduce costs [5]. In this framework, there has been a growing interest in energy modelling studies, in order to understand how to optimise energy consumption in buildings [6].

In this context, on the 28 October 2020, the Sustainable Places 2020 virtual conference took place, where nine EU-funded research projects showed their work and exposed some innovative solutions advanced in their projects. All of them highlighted the challenges that the industry continues to face under the digital transformation [7]. Recently, the construction sector has been identified as the poorest in Europe, in terms of productivity, as there exist many difficulties in this sector to integrate digital innovations [8].

Over the last two decades, BIM has been used in the construction sector, with the focus to improve collaboration between different stakeholders [9], facilitate the fast creation of different designs, and to decrease its inefficiencies on-site and among the project disciplines [10]. It has also become the core of the cyber-physical system and a great tool to improve the energy efficiency concept in building design, once it is able to improve the quality and performance of the construction life-cycle under the industry 4.0 paradigm [11]. At present, BIM is crucial for bridging the gap between digitalisation and the construction field. The digital information management tools offered by BIM make it possible to optimise and better control constructive processes, from the design stage to the management of the building's life-cycle and maintenance [12].

BEMs are the basis of energy performance certificates (EPCs) and assessments. Both EPCs and assessments should be user-friendly, profitable, and more reliable, in order to give investors confidence in the energy efficiency sector. Then, the certification processes and BEMs should achieve these requirements [13]. In addition, BEMs can be organized into three categories: Physics-based models (white-box) [14], pure data-driven or statistical models (black-box) [15], and hybrid models (grey-box) [16]. In this paper, white-box models were considered, as they enable the definition of all the elements that influence the building's energy behaviour (e.g., the weather, internal loads, construction) [17,18] and, therefore, have a clear connection with BIM components. Although heating ventilation air conditioning (HVAC) systems are also important to the energy analysis, they were not considered in this study.

Furthermore, interoperability between BIM and BEM could be a step forward in reducing costs and saving model re-creation time during the design phase. BIM has the potential to streamline the production of energy models, by storing important data such as building geometry, construction typology, and thermal properties [19], as well as enabling the iteration of efficient designs in a shared environment [20]. In addition, BEMs are key elements in understanding how to reduce energy consumption and how to improve it [21]. Furthermore, BEM tools and measures can carry out energy simulations, analyse energy needs, and improve the project design [22]. Due to this, at present, there is a significant interest in simplifying the creation of a BEM from the BIM authoring tool, by sharing and exporting the data from the architectural model $[23,24]$.

However, BIM-BEM interoperability is one of the existing digital gaps at the design stage. Although BIM is considered a multidisciplinary tool, interoperability issues still prevent many BIM applications in relevant industries [25]. The lack of compatibility between the BIM model and the energy simulation applications, the repetitive manual operations required to create a BEM, and the non-standardised and subjective process [26] usually result in data loss and misinterpretation, especially when this was been taken into account in the first phase of the design step $[27,28]$. Sanhudo et al. also concluded that the main problem in transferring data between BIM and BEM is the information loss, which can lead to a rework consisting of re-entering the BIM stored information into the energy model [29]. Furthermore, Kamal and Memari were in accordance with Sanhudo et al., defending that BIM contributes to the easy handling of data, which can leads to automation in building energy modelling and simulation, as well as providing up-to-date energy models with real-time information. They also emphasised the need for clear standards and solutions for the BIM to BEM interoperability process [30]. 
The BIM-BEM process consists of three parts-BIM tool, model schema exchange format, and BEM software-interoperability issues may appear in any or all of these; not only in the energy simulation application. This means the problems that are encountered are not exclusively due to the limited ability of BEM tools to translate input data from BIM [31]. In order to transfer the BIM information to a building energy analysis software, many file formats exist, such as hypertext markup language (HTML), extensible hypertext markup language (XHTML), building construction extensible markup language (bcXML), industry foundation classes extensible markup language (IFCXML), industry foundation classes (IFC), and green building extensible markup language (gbXML), the last two being the main open BIM standards [32]. Open standards enable and facilitate the integration and collaboration of different professionals from all over the world, by providing a common basis around which research, development, and deployment activities can be organised, as has been done in the IBPSA Project 1 [33].

These open standards are commonly used in the BIM-BEM procedure, and there is an ongoing discussion about which standard is the best for the data exchange process. On the one hand, IFC reproduces a complete building project and, therefore, generates a complex data schema and larger size data files. On the other hand, gbXML provides a more flexible and direct approach to energy analysis [34]. Both of them transfer the material properties, data for HVAC systems, and thermal zones; however, only gbXML provides location data [30]. However, Gao et al. drew different conclusions about gbXML and IFC data transfer. They invented a classification process called BIM-based-BEM, which divides the information transfer from BIM into six categories: Geometry (step 1), material (step 2), space type (step 3), thermal zone (step 4), space load (step 5), and HVAC (step 6). After analysing the information transfer between distinctive softwares, they verified that the IFC format is step 1 and gbXML is step 3. In addition, they concluded that the information transfer is not user-friendly, as there are many steps between BIM and BEM [35,36]. In summary, BIM-BEM interoperability has not yet become as widespread as expected, due to the information loss, lack of a standard, software not being as interoperable as claimed by their suppliers, and the data standards not having been clearly determined [37].

Due to the need to improve BIM-BEM interoperability in the design phase, this work aims to verify and evaluate whether there is an automated or semi-automated BIM to BEM workflow, comparing the importing of gbXML and IFC in three BEM software: Design Builder, Open Studio, and CYPETHERM HE. These software were chosen as they are all based on EnergyPlus [38], which is a notable and reliable energy simulation engine. EnergyPlus does not have a user-friendly interface; therefore, these three different software were chosen to run the engine. Firstly, Design Builder [39] is the most global tool, used by most professionals in the simulation sector. Secondly, Open Studio [40] was chosen because it is an open-source software, although it does not have the ability to model from scratch; instead relying on SketchUp to do so which, by contrast, is no longer a free software. Both Design Builder and Open Studio were created for energy simulations and they are the most popular tools for BEM creation. Finally, CYPETHERM HE [41] is a tool that has wide international outreach and is part of the complete CYPE package, made up of other software related to architecture, engineering, and construction. Furthermore, this software is BIM-oriented and should have a good interoperability process.

Furthermore, we intend to lead to an improvement in the building design stage through this research, in terms of speeding it up, obtaining more precise energy data, and encouraging professionals in the construction field to gain confidence in the process and helping them to be aware of the limitations. This work could as well be a guide for $\mathrm{BIM} / \mathrm{BEM}$ software developers, in order to find new paths to overcome the main problems that the process is now facing.

For this purpose, two case studies at different scales were chosen: A single-family house and a warehouse. In both cases, we started from a BIM model and explored different paths to reach the BEM. The difficulties and the problems detected in the thermal envelope in the interoperability process were investigated. 
The rest of this paper is organized as follows: Section 2 explains the method, which consists of the BIM exporting formats and the BEM importing software. Section 3 analyses and discusses the results. Section 4 presents the conclusion and research directions for future works.

\section{Method}

The aim of this research was to verify whether there is an automated workflow between building information modelling (BIM) and building energy model (BEM) software, and how this interoperability works. The idea was to experiment with three different flows from BIM to BEM, which had the same BIM authoring tool in common and the same calculation engine in the BEM software: Energy Plus. For this study, 3D models were made in Autodesk Revit 2020 and the three BEM programs that were chosen were Design Builder, Open Studio, and CYPETHERM HE. Figure 1 represents the paper's structure and process.

The paper was divided into two main steps: The first one is about the interoperability from BIM to BEM for two case studies, a residential building and an industrial warehouse. For both projects, the files were exported from Revit in two formats: green building extensible markup language (gbXML) and industry foundation classes (IFC). To export the gbXML file, we needed to create an analytical model in Revit, which was not necessary for the IFC format. However, to import the IFC file into CYPETHERM HE, another software was required (Open BIM Analytical Model), in order to generate an analytical model based on the IFC format without errors. At the end of this step, a comparison of the gbXML and IFC import results was made to identify the interoperability strengths and weaknesses. In addition, a qualitative evaluation of this first step was carried out, in order to verify which of the three processes was more feasible, under the vision of an architect user of the software.

The last step was a comparison of the simulation results of the first step. The extracted files from BIM were imported into the BEM software: Design Builder and Open Studio were used for gbXML and CYPETHERM HE for IFC. To make the comparison more precise, we focused on the energy envelope performance through windows and opaque surfaces. In this way, none of the data about people, equipment, lights, infiltration, or HVAC were selected and, therefore, we could explore only the parameters affected by the interoperability construction process in more detail.

As a result, we intended to discern whether there exists an automated or semiautomated workflow between BIM and BEM.

\subsection{BIM Exporting Formats}

At present, many BIM authoring tools support the gbXML and IFC data formats. In this paper, we chose Autodesk Revit 2020 as the BIM engine, in which only the geometry and envelopes of the buildings were modelled. As mentioned previously, HVAC was not considered in the BEM.

The first case study is a residential building of $143.60 \mathrm{~m}^{2}$, with two floors (Figure 2) and 13 thermal zones. It has a simple and straight-line geometry, with vertical circulation per staircase. Its Revit file had 4.20 megabytes of information.

On the other hand, the second case study was a much bigger and more complex building (Figure 2). It is an industrial warehouse of $9.677 \mathrm{~m}^{2}$, with three floors and a basement, in which 21 thermal zones were defined. Although it has a simple geometry, the roof is curved, as well as some of the walls. In comparison with the residential case, this one had 75.15 megabytes of information. 


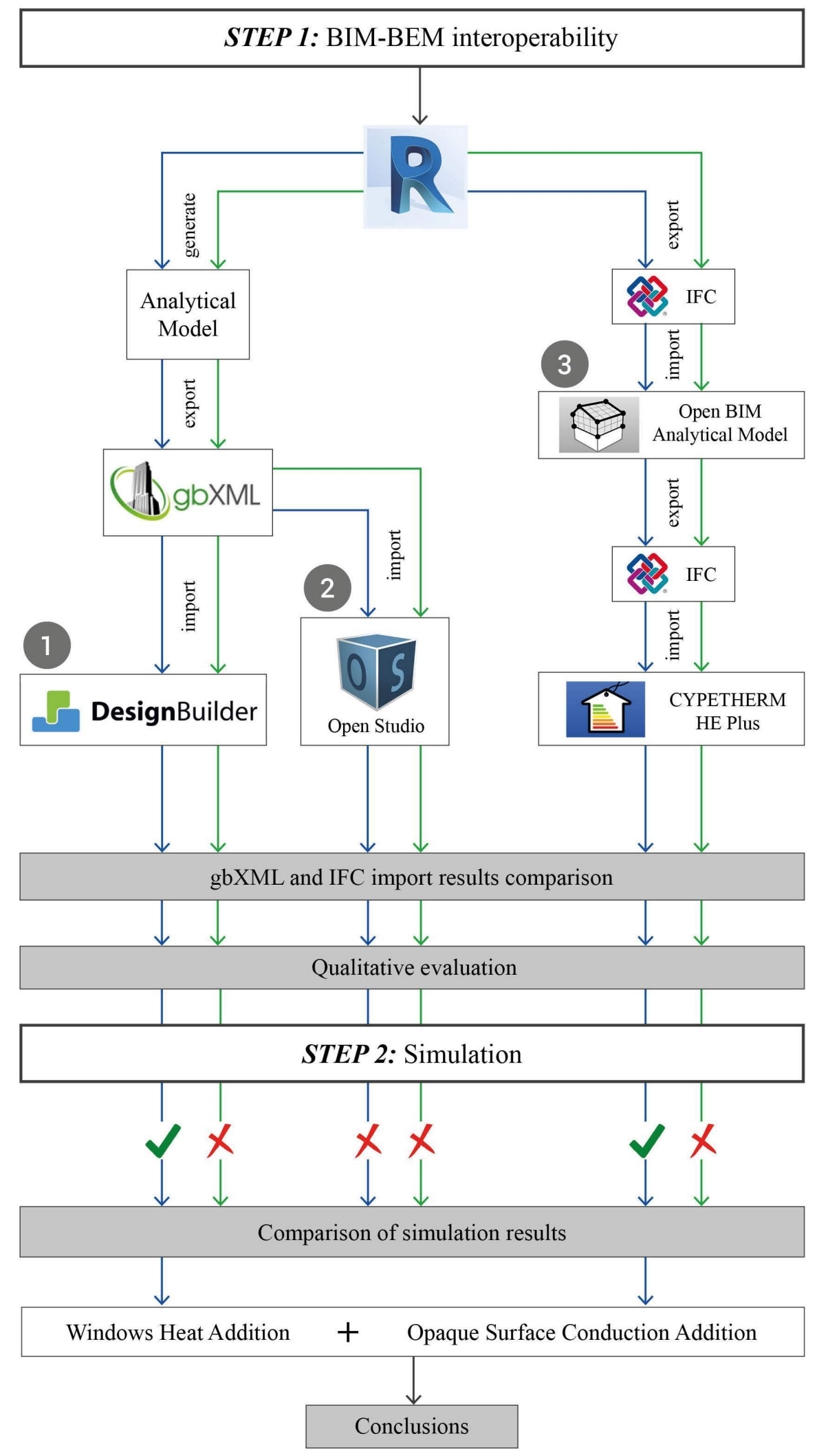

X Interoperability: No $\checkmark$ Interoperability: Yes $\longrightarrow$ Residential building $\longrightarrow$ Warehouse building

Figure 1. Paper process diagram. Numbers to follow the diagram and import processes. 

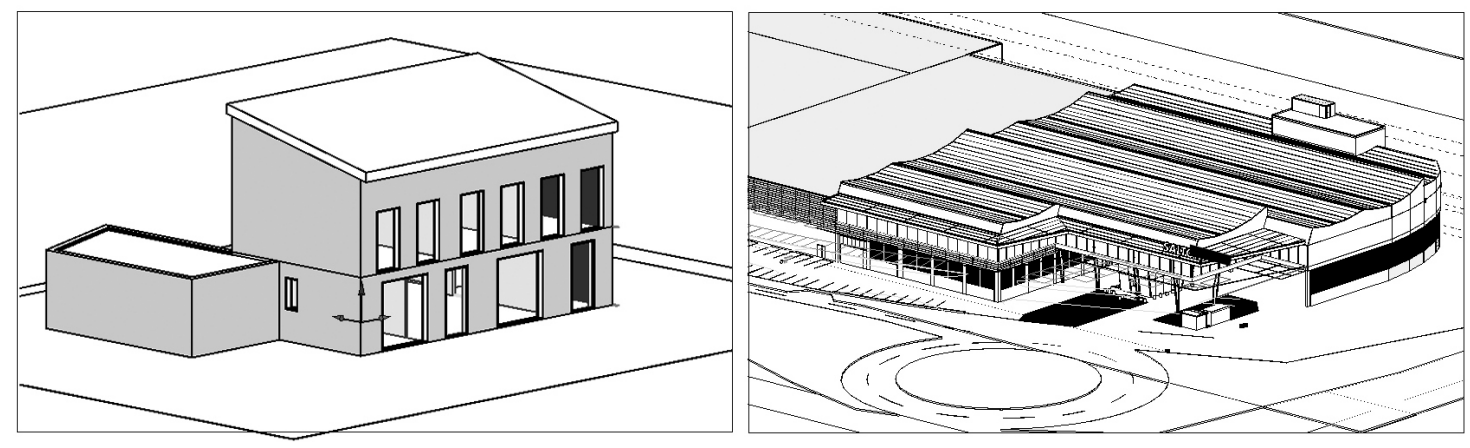

Figure 2. Building information modelling (BIM) models of the residential and warehouse buildings.

\subsubsection{Green Building XML (gbXML)}

The Green Building XML (gbXML) schema, developed by Green Building Studio Inc., is focused on environmental data. It was originally developed to enable interoperability between the building design in CAD softwares and energy analysis tools [34]. However, $\mathrm{gbXML}$ also attends to exchange data among diverse simulation instruments. In its format, the geometric and weather data, user profiles, and energy information are exchanged. Nevertheless, some parameters about building HVAC components are discarded [42].

At the moment of exporting the gbXML file from Revit, some decisions must be made. First, it is necessary to create an analytical model, and to check, in the Revit export gbXML interface, if the spaces and the geometry are defined precisely. If there is any error with both characteristics, it would not be able to conclude the gbXML export. Secondly, in order to achieve good interoperability, some parameters must also be activated in Revit export gbXML, such as rooms and detailed elements; otherwise, in the gbXML, there will be a lack of information needed for the creation of the BEM, in reference to the geometry and the envelope materials.

It is possible to see, from Figure 3, that all the thermal zones of the residential building were generated correctly in the gbXML file. Contrarily, the warehouse study presented a particularity in its analytical model and in the gbXML export. Its analytical spaces' 3D view did not show all the thermal zones that were created. However, at the point of the gbXML export, it can be seen that the zones were generated properly.
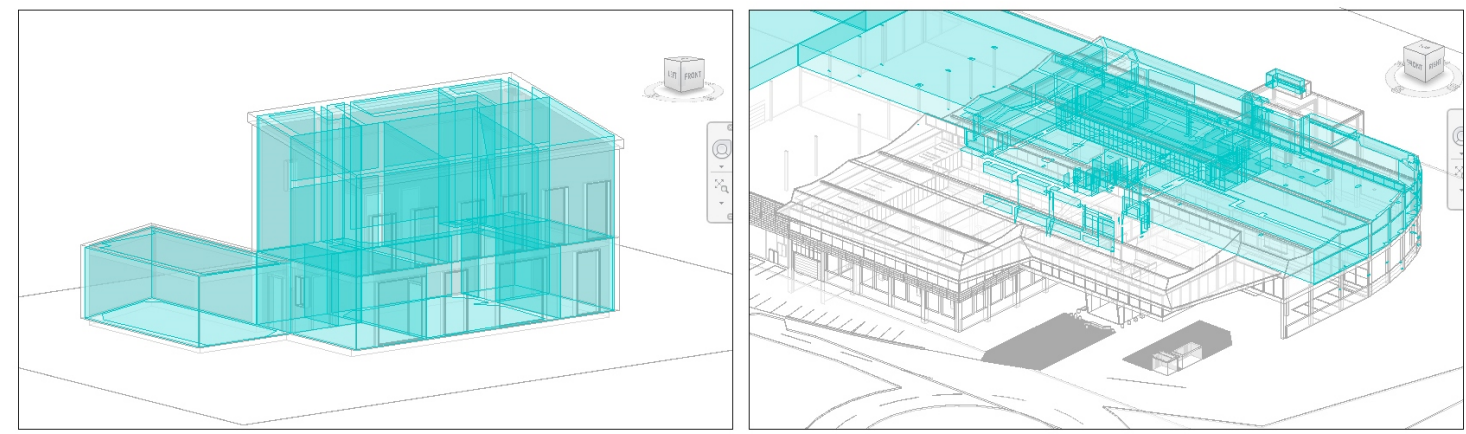

Figure 3. Analytical model of the residential and warehouse buildings.

\subsubsection{Industry Foundation Classes (IFC)}

The industry foundation classes (IFC) were developed by international association interoperability (IAI), but are now administrated by the buildingSMART alliance. They are the only 3D object-oriented open standards that use BIM. In contrast to gbXML, the aim of the IFC format is to provide a single basis for the exchange of information in the field of construction and facility management [43]. The IFC schema is more extensive and complex than the gbXML format, and supports, in addition to a good geometric representation, semantic data enrichment [44]. 
Although there is an automated IFC export from Revit using the BIM collaboration plug-in developed by CYPE, the IFC files for both case studies were exported manually. In order to guarantee proper interoperability, in the Revit export interface, the phase where the thermal zones were created must be selected. Otherwise, the room data will not be transferred.

\subsection{BEM Importing Software}

As mentioned above, Design Builder and Open Studio were the software selected to import the gbXML file, while CYPETHERM HE was used to import the IFC format.

\subsubsection{Design Builder}

First of all, the gbXML file was imported in Design Builder, which is a software that allows for the editing of BEM geometry, spaces, and materials. In this research, as the purpose was to study the interoperability from BIM to BEM, any modification was made in the imported model. Nevertheless, at the moment of the gbXML file insert, some parameters were activated and some templates were changed, as data related to the typology template, weather file, ideal loads, and occupation schedule were not detailed in Revit and, therefore, could not be imported with the gbXML file.

In the interface, "Import BIM Model" was selected to import the thermal properties and the model as building blocks. The use of these parameters guaranteed that the materials defined in Revit would be transferred into Design Builder and that the model would be constructed with thermal zones. The activity template chosen was according to the type of the building and, in the openings tab, the layout of the external windows was defined as none. If these elements had not been defined properly, the BEM model would not work correctly and this could not be considered an interoperability error but, rather, a mistake in the configuration of the BEM file.

\subsubsection{Open Studio}

In order to compare the transfer of the data, the gbXML file was imported into the Open Studio software. Differently to Design Builder, Open Studio only allows for the change of the materials and the thermal zones and, if any adjustment to the geometry is needed, the SketchUp Open Studio plug-in software must be used. Similarly to Design Builder, it was also necessary to carry out some actions in Open Studio, such as changing the typology template, choosing the appropriate timetable, activating the ideal loads, and selecting the weather file.

\subsubsection{CYPETHERM HE}

Initially, three options for BEM software were considered to import IFC: CYPETHERM HE, Space Boundary Tool (SBT), and Open Studio. Nevertheless, only CYPETHERM HE was actually available. The SBT software, from the Lawrence Berkeley National Laboratory, is no longer updated (since 2014). On the other hand, Open Studio can import gbXML, as was previously explained, but when trying to import IFC files, an intermediate program called BIMserver was necessary. The installation process of the BIMserver required a high level of expertise and, therefore, this workflow was discarded.

CYPETHERM HE is continuously updated and its interoperability between BIM and BEM is an easy and intuitive process. Despite the fact that an intermediate software is needed to transfer the IFC data to CYPETHERM HE (Open BIM Analytical Model), the workflow is simple and does not require expert knowledge.

In the CYPETHERM HE import interface, it is possible to select a typology directory, which refers to the project materials. In this case, as it was not possible to transfer the envelope materials and its thermal properties from Revit and there was no typology directory created in CYPETHERM HE, it was necessary to generate all the construction systems in this tool. Once this typology is generated, it can be saved and be used in any other project. 
Before importing the IFC file into the BEM tool, the Open BIM Analytical Model software was used to create an analytical model and verify the extracted data, as it refers to its dimensions, geometry, materials, and any inconsistency between the building geometry elements. As a result, the IFC data of the residential case was extracted correctly from the BIM authoring tool. All the 13 thermal zones and the envelope materials were transferred. Furthermore, the model was constructed properly and its dimensions were the same as in the BIM (see Figure 4).

On the other hand, the industrial warehouse model in the Open BIM Analytical Model software seemed to be constructed properly, but only 19 thermal zones were imported. It was found out that two thermal zones of the first floor were missing in the IFC data. No reason was found, as to why these zones were not extracted, as the same procedure was followed within all the thermal zones.

In order to cast light on the problem, the IFC of the warehouse was imported into the Solibri Anywhere software and the same issues appeared as in the Open BIM Analytical Model. The reason for this seemed to be connected with the generation of the model from the IFC as a consequence of a wrong transfer of the BIM data to the IFC format and, therefore, was not dependent on the type of software used. This is clearly an interoperability problem related to the IFC format.
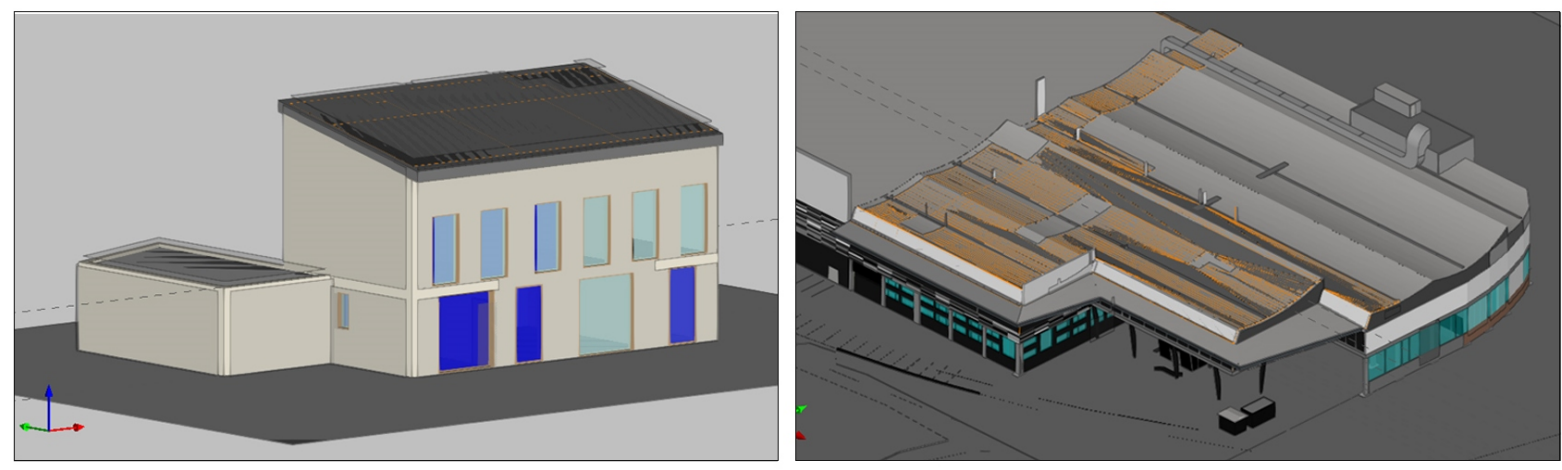

Figure 4. IFC files imported into Open BIM Analytical Model.

\section{Results and Discussion}

\section{1. gbXML Import Results}

\subsubsection{Residential case in Design Builder}

As it is possible to see in Figure 5, all the thermal zones established in the Revit file of the residential building were correctly imported into Design Builder. Furthermore, the library of materials was successfully transferred and a new template called "gbXML" was generated.

However, although the model was perfectly constructed in Revit, it had some problems in Design Builder. First, the model dimensions in the BEM software were not the same as in BIM. In Design Builder, the building was 1.70\% smaller than in Revit and, consequently, the volumes of the thermal zones were also smaller. Another problem was found concerning the model surfaces. In the north facade, there were errors in recognizing the walls and the roof and the first floor was not constructed accurately. In addition, some of the walls were imported without the construction assignment. 


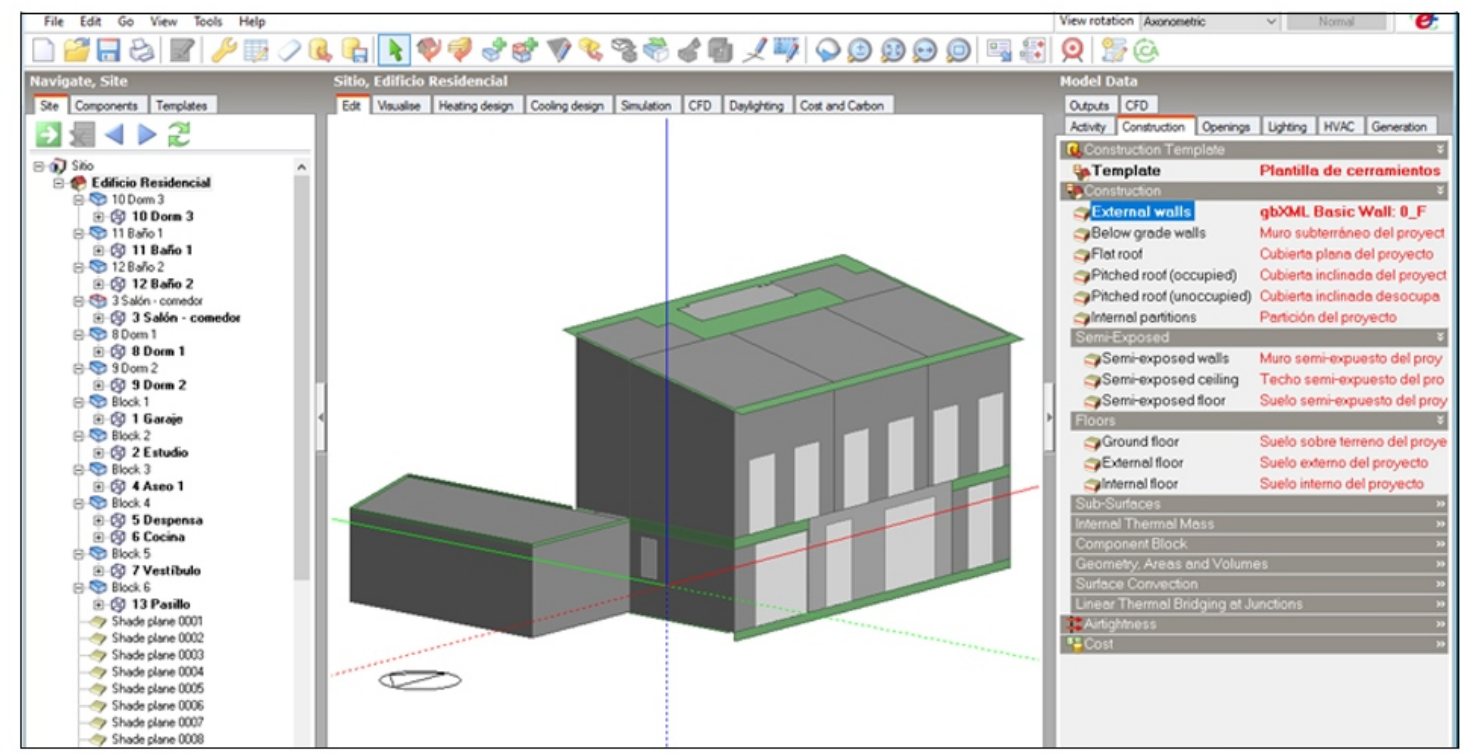

Figure 5. Residential green building extensible markup language (gbXML) file imported in Design Builder.

\subsubsection{Warehouse Case in Design Builder}

On the other hand, the industrial warehouse gbXML file showed many more problems than the first case study. Some walls and roof construction systems were created as shadow elements, presented apertures in their surfaces, and did not assemble well with each other. Furthermore, the roof was divided into many small parts, some of which were recognized as walls or as windows, while some of them were missing (see Figure 6). Moreover, some walls were generated automatically, although they did not exist in the BIM tool.

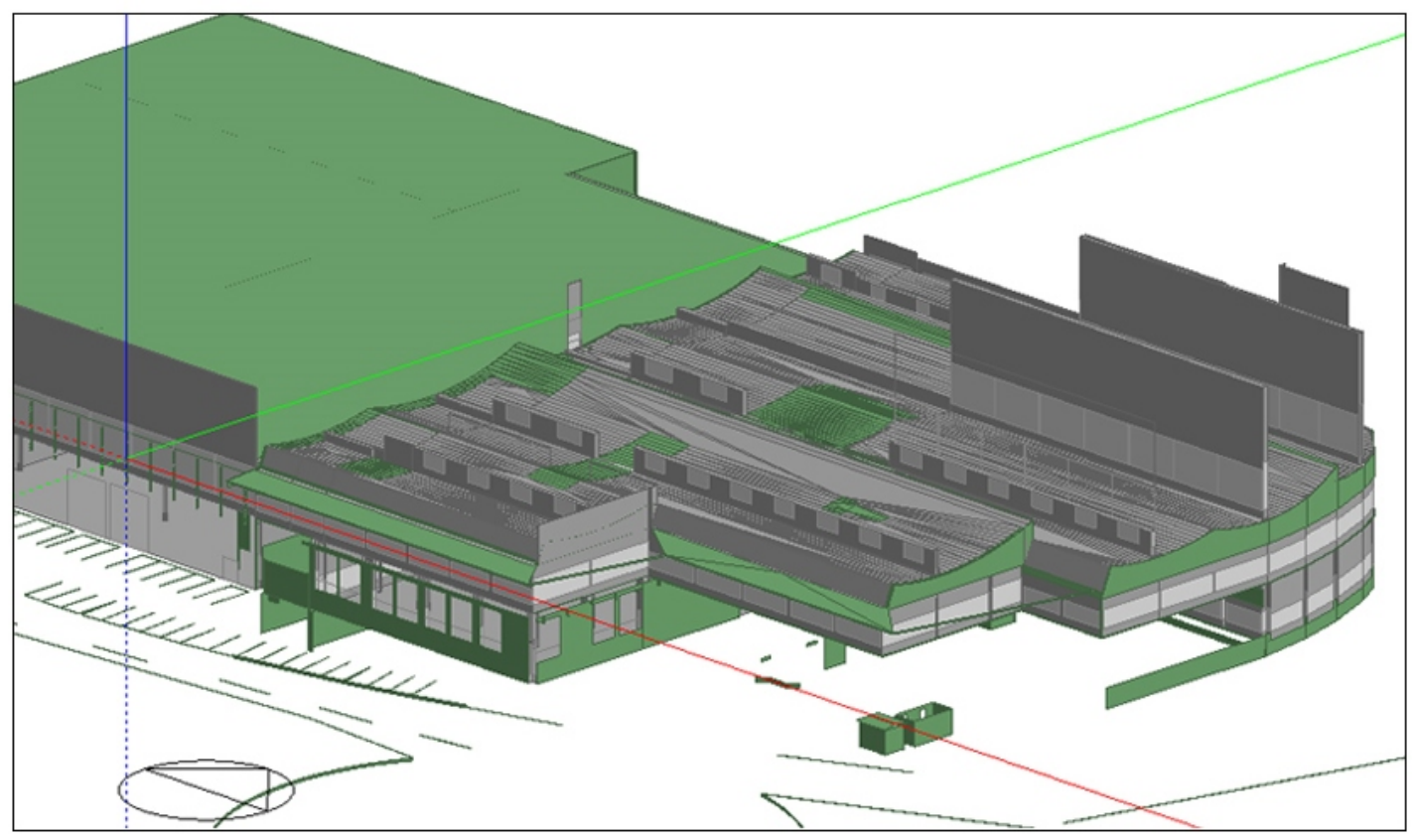

Figure 6. Warehouse gbXML file imported in Design Builder.

Table 1 summarizes the errors encountered in the gbXML file import into Design Builder. In summary, the issues found were very similar in both models. However, it was noticed that, when the file was bigger and had more data, more problems appeared during model creation in BEM, mainly with respect to the construction of the thermal envelope 
(walls, floors, and roof). Moreover, both models showed different dimensions from Revit, which could not be corrected at the importing step. The only way to guarantee that the model has exactly the same external dimensions as in the BIM, would be to not import it as "building blocks". Otherwise, all of the model would be created as a building component, without the generation of thermal zones. Therefore, it is better to accept a percentage of dimension error than to have to build all the thermal zones, which were already made in the BIM authoring tool.

Table 1. Comparative table between the gbXML files imported in Design Builder.

\begin{tabular}{|c|c|c|c|}
\hline & \multirow[b]{3}{*}{ The model } & \multicolumn{2}{|c|}{ Design Builder } \\
\hline & & \multicolumn{2}{|c|}{ gbXML from Revit } \\
\hline & & Residential case & Warehouse case \\
\hline \multirow{6}{*}{ Dimensions } & $\begin{array}{l}\text { 1. External dimen- } \\
\text { sions. }\end{array}$ & $\begin{array}{l}\text { Some walls were } 4 \% \text { smaller and others } \\
\text { were } 2 \% \text { bigger than BIM }\end{array}$ & Walls $0.56 \%$ smaller than BIM. \\
\hline & 1. Solution. & Modify the model in Design Builder. & Modify the model in Design Builder. \\
\hline & $\begin{array}{l}\text { 2. Thermal zones } \\
\text { area. }\end{array}$ & $\begin{array}{l}\text { Some areas were } 4 \% \text { smaller and other } \\
\text { up to } 10 \% \text { bigger than in the BIM. }\end{array}$ & Correct. \\
\hline & 2. Solution. & Modify the model in Design Builder. & - \\
\hline & $\begin{array}{l}\text { 3. Thermal zones } \\
\text { volume. }\end{array}$ & $\begin{array}{l}\text { The volumes are at least } 6 \% \text { bigger than } \\
\text { in the BIM. }\end{array}$ & Correct. \\
\hline & 3. Solution. & Modify the model in Design Builder. & - \\
\hline \multirow{4}{*}{ Geometry } & $\begin{array}{l}\text { 4. Zones recogni- } \\
\text { tion. }\end{array}$ & Correct. Total of 13 zones. & Correct. Total of 21 zones. \\
\hline & 4. Solution. & - & - \\
\hline & 5. Building surfaces. & $\begin{array}{l}\text { North walls and parts of the roof im- } \\
\text { properly constructed and presented } \\
\text { some gaps. First floor is missing. Parts } \\
\text { of the thermal envelope were recog- } \\
\text { nized as shadow elements. }\end{array}$ & $\begin{array}{l}\text { North walls and parts of the roof im- } \\
\text { properly constructed and presented } \\
\text { some gaps. Ground floor is missing. } \\
\text { Parts of the thermal envelope were rec- } \\
\text { ognized as shadow elements. }\end{array}$ \\
\hline & 5. Solution. & Modify the model in Design Builder. & Modify the model in Design Builder. \\
\hline \multirow{6}{*}{ Materials } & 6. Building materials. & $\begin{array}{l}\text { Correct. Two folders called "Imported" } \\
\text { were created: One for constructive sys- } \\
\text { tems and another for materials. }\end{array}$ & $\begin{array}{l}\text { Correct. Two folders called "Imported" } \\
\text { were created: One for constructive sys- } \\
\text { tems and another for materials. }\end{array}$ \\
\hline & 6. Solution. & - & - \\
\hline & $\begin{array}{l}\text { 7. Material thick- } \\
\text { ness. }\end{array}$ & Correct. & Correct. \\
\hline & 7. Solution. & - & - \\
\hline & $\begin{array}{l}\text { 8. Material thermal } \\
\text { properties. }\end{array}$ & $\begin{array}{l}\text { Correct. The properties that do not ap- } \\
\text { pear in Revit were automatically filled } \\
\text { in Design Builder. }\end{array}$ & $\begin{array}{l}\text { Correct. The properties that do not ap- } \\
\text { pear in Revit were automatically filled } \\
\text { in Design Builder. }\end{array}$ \\
\hline & 8. Solution. & - & - \\
\hline
\end{tabular}

\subsubsection{Residential Case in Open Studio}

As was mentioned above, Open Studio was also used to import the gbXMl file, and some steps were executed. First, it was verified that the imported data of the materials and the thermal zones were in line with those determined in Revit. Second, with respect 
to the errors, it was not possible to measure the model facades in Open Studio. Then, the SketchUp 2017 software and the plug-in Open Studio for SketchUp were used to import the Open Studio file, in order to check whether the model dimensions were the same in the BIM and BEM software. However, the building dimensions were between $1 \%$ to $6 \%$ smaller and the thermal zones were $0.85 \%$ to $8 \%$ bigger than in Revit. These problems may have occurred because of the transferred data of the wall dimensions, if they were automatically recognized from external to external walls or from the middle of the internal walls. Unfortunately, this recognition cannot be controlled, either in the export of the gbXML or during its import into the BEM software.

Finally, the geometry was not generated properly: As in Design Builder, the first floor and some parts of the wall of the north facade were recognized as shadow elements. This might have occurred because it is only necessary to model the building surfaces that enclose the thermal zones and the floor is modeled as a unique line in the BEM tool. Therefore, as the model was generated automatically, every space that was left over as a shadow element was recognized. In addition, some walls had gaps that did not appear in Revit (see Figure 7).
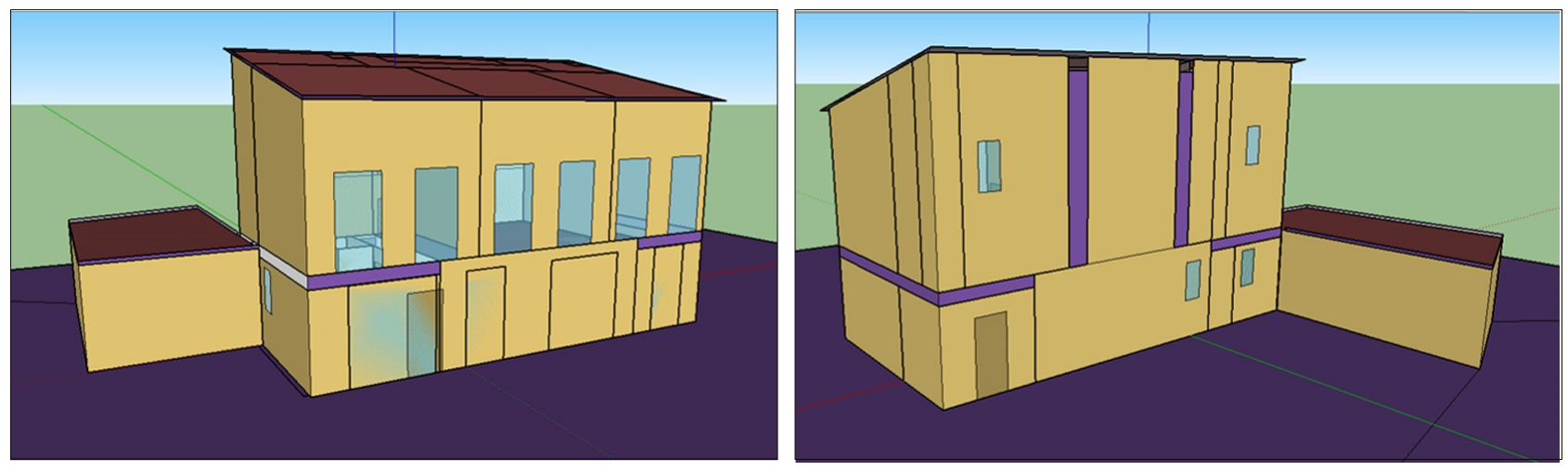

Figure 7. Residential gbXML file imported in Open Studio.

\subsubsection{Warehouse Case in Open Studio}

The model of the industrial warehouse in Open Studio was built with less inconsistencies than in Design Builder and all 21 thermal zones were imported. However, it also showed some errors in the construction of the walls and in its assembly with other constructive systems, which directly affected the thermal zone areas and volumes. The roof, again, was divided into many pieces, in which some parts were considered as shadow elements. Additionally, the windows were missing (see Figure 8).

As the same phenomena occurred in Design Builder, it can be noted that, in the gbXML import in Open Studio, the bigger and more complex the building, the more issues appear (mainly on the envelope). It would not be a problem if the model had the same size as the residential case, as there would not be many difficulties to be corrected. On the other hand, if the project had the same proportion or bigger than the warehouse, it would be complicated to verify all the model issues and to fix them. Finally, Table 2 compiles the errors and possible resolutions for each case. 


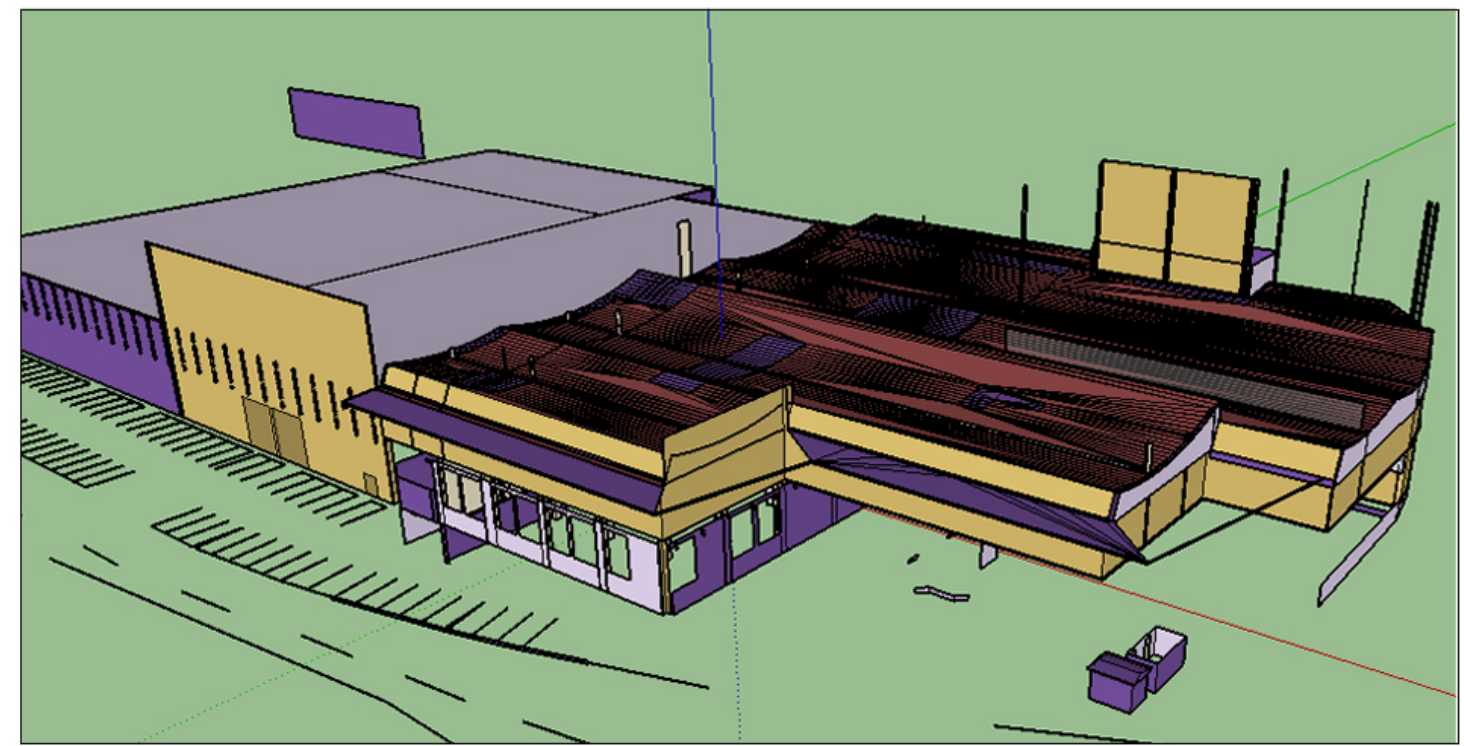

Figure 8. Warehouse gbXML file imported in Open Studio.

Table 2. Comparative table between the gbXML files imported in Open Studio.

Open Studio

gbXML from Revit

The model

1. External dimensions.

1. Solution.

Dimensions

2. Thermal zones area are between $0.85 \%$ to $8 \%$
bigger than in the BIM.

2. Solution.

3. Thermal zones volume.

3. Solution.

4. Zones recognition.

\section{Solution.}

Geometry

5. Building surfaces.

5. Solution.
Modify the model in SketchUp.

Model between $1 \%$ to $6 \%$ smaller than in the BIM.

Modify the model in SketchUp.

The volumes are between $4 \%$ to $12 \%$ bigger than in the BIM.

Modify the model in SketchUp.

Correct. Total of 13 zones. North walls and parts of the roof im-
properly constructed and presented some gaps. Facade of the first floor transferred as a shadow element.

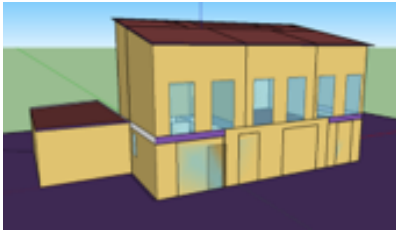

Residential case

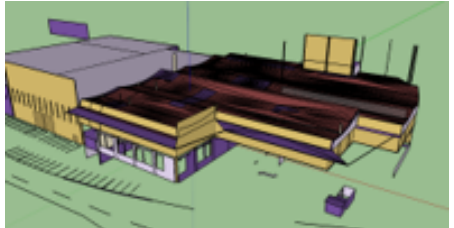

Warehouse case

\section{Correct.}

As the thermal zones were subdivided and some parts were missing, it was not possible to measure its area. Modify the model in SketchUp.

As the thermal zones were subdivided and some parts were missing, it was not possible to measure its area. Modify the model in SketchUp.

Correct. Total of 21 zones.

Walls and parts of the roof improperly constructed, divided into many small parts and presented some gaps. Windows were missing. 
Table 2. Cont.

\begin{tabular}{|c|c|c|c|}
\hline & & \multicolumn{2}{|c|}{ Open Studio } \\
\hline \multirow{6}{*}{ Materials } & $\begin{array}{l}\text { 6. Building } \\
\text { materials. }\end{array}$ & $\begin{array}{l}\text { Correctly imported, but some walls do } \\
\text { not have the same construction name } \\
\text { as in Revit. }\end{array}$ & $\begin{array}{l}\text { Not all the construction systems were } \\
\text { transferred and some walls do not have } \\
\text { the same construction name as in Revit. }\end{array}$ \\
\hline & 6. Solution. & $\begin{array}{l}\text { Change the name in Open Studio or in } \\
\text { SketchUp. }\end{array}$ & $\begin{array}{l}\text { Modify the model in Open Studio or in } \\
\text { SketchUp. }\end{array}$ \\
\hline & 7. Material thickness. & Correct. & $\begin{array}{l}\text { For those materials that were imported: } \\
\text { Correct. }\end{array}$ \\
\hline & 7. Solution. & - & 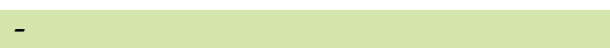 \\
\hline & $\begin{array}{l}\text { 8. Material thermal } \\
\text { properties. }\end{array}$ & $\begin{array}{l}\text { In Open Studio, there are some proper- } \\
\text { ties that do not appear in Revit and, in } \\
\text { this case, they were automatically filled } \\
\text { in by Open Studio. }\end{array}$ & $\begin{array}{l}\text { In Open Studio, there are some proper- } \\
\text { ties that do not appear in Revit and, in } \\
\text { this case, they were automatically filled } \\
\text { in by Open Studio. }\end{array}$ \\
\hline & 8. Solution. & - & - \\
\hline
\end{tabular}

\subsection{IFC Import Results}

\subsubsection{Residential Case in CYPETHERM HE}

Although CYPETHERM HE enables IFC import directly in the software, it has been analysed that it is better to use the IFC exported from an Open BIM Analytical Model. When the IFC file was imported in CYPETHERM HE directly from Revit, all the thermal zones showed $0 \mathrm{~m}^{2}$ and $75 \mathrm{~m}^{3}$. However, after exporting the IFC from the Open BIM Analytical Model and importing it into CYPETHERM HE, the thermal zone dimensions were not accurately transferred. The dining room thermal zone presented the biggest difference from Revit, as its volume was $180 \%$ bigger than in the BIM. The other zones, in turn, were about $6 \%$ to $12 \%$ bigger than in Revit.

Another problem found was the creation of two internal walls in the group of external walls that could not be deleted. In addition, the floor that was in contact with the ground was not transferred and, so, CYPETHERM HE considered this floor as a slab between floors, which could be a relevant issue when analysing the building energy demand. In contrast, all windows were properly imported, according to their dimensions, with only one window missing (see Figure 9).

Similarly to Open Studio, it is possible to edit the materials of the building envelope and to delete and add thermal zones in CYPETHERM HE. However, once a thermal zone or a building surface is added, it cannot be referred to as specific space and, so, it is pointless to make any change, in this aspect, in CYPETHERM HE. If there is necessity for modifying the model geometry or thermal zones, it can be done in the BIM authoring tool, or in another CYPE software called IFC Builder.

\subsubsection{Warehouse Case in CYPETHERM HE}

On the other hand, as happened at the moment of importing the warehouse IFC in Open BIM Analytical Model, not all the thermal zones were imported in CYPETHERM HE (see Figure 9). This might be a problem relating to extracting the data from the BIM authoring tool to the IFC file, once it worked properly with the gbXML format.

Although the construction of the model seemed accurate, the thermal zones were built with many errors. Firstly, some of the zones did not have all their enclosures or some surfaces presented gaps; furthermore, they did not have the correct dimensions, compared to the BIM. The thermal zone areas and volumes were bigger than in Revit; the same happened in the residential case. Moreover, as occurred in Design Builder, some surfaces of the thermal envelope were divided into many small parts, despite having the same constructive system. 

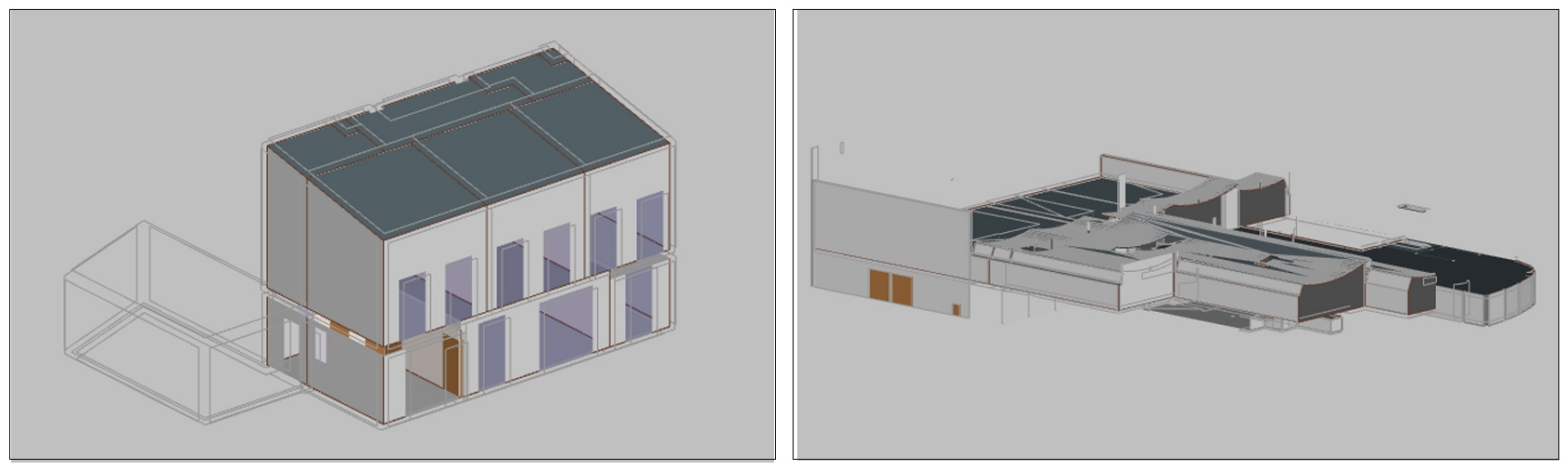

Figure 9. Residential and warehouse industry foundation classes (IFC) files imported in CYPETHERM HE.

Finally, as can be seen in Table 3, the problems detected in the IFC import in CYPETHERM HE increased with the size of the building and its complexity. In the residential case, CYPETHERM HE was able to verify each constructive system and detect if there were any missing elements. Nonetheless, the warehouse building had its surfaces divided into many parts; in some of which the construction systems were changed and, as consequence, it became difficult to measure and evaluate them. In addition, contrarily to Design Builder, in CYPETHERM HE, it is not possible to correct model issues. One way to solve these problems would be to import the IFC file into IFC Builder and to try to fix them there; however, this work would take a long time and might still not be totally free of error.

Table 3. Comparative table between IFC imported in CYPETHERM HE.

\section{CYPETHERM HE}

\section{IFC from Revit}

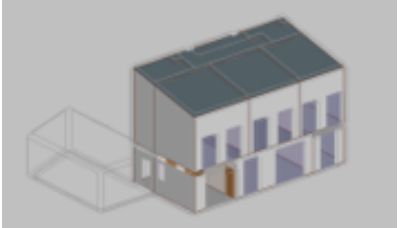

Residential case

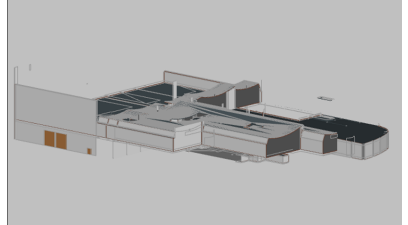

Warehouse case
The model

1. External dimensions.

1. Solution.

2. Thermal zones

Dimensions area.

2. Solution.

3. Thermal zones volume.

3. Solution.
Model between $0.70 \%$ to $7.50 \%$ smaller than in the BIM.

It is not possible to correct the external dimensions in CYPETHERM HE.

Areas between $6 \%$ to $12 \%$ bigger than in the BIM.

It is not possible to correct the thermal zone areas in CYPETHERM HE.

Volumes between $12 \%$ to $134 \%$ bigger than in the BIM.

It is not recommended to modify the thermal zone volumes in CYPETHERM HE.
The dimensions were measured selecting the facades. Some of them were more than $20 \%$ bigger and others $10 \%$ smaller than in the BIM.

It is not possible to correct the external dimensions in CYPETHERM HE.

Areas between $1 \%$ to $5 \%$ bigger than in the BIM.

It is not possible to correct the thermal zone areas in CYPETHERM HE.

Volumes between $27 \%$ to $180 \%$ bigger than in the BIM.

It is not recommended to modify the thermal zone volumes in CYPETHERM HE. 
Table 3. Cont.

\section{CYPETHERM HE}

4. Zone recogni- Correct. Total of 13 zones. tion.

\section{Solution.}

Geometry 5. Building surfaces.

5. Solution

6. Building materials.

It is not possible to correct the building geometry in CYPETHERM HE.

The name of the constructive system

Gaps in the surfaces of the thermal envelope. Some walls and the ground floor had the wrong recognition of their constructive system. One window was missing.

was imported correctly, but none of the materials could be imported from Revit.

6. Solution. Create the typologies in CYPETHERM HE.

Materials

7. Material thickness.

None of the materials could be imported from Revit.

7. Solution. Create the typologies in CYPETHERM HE.

8. Material thermal None of the materials could be improperties.

8. Solution. ported from Revit. Create the typologies in CYPETHERM HE.
Incorrect. Total of 19 zones, not 21.

It is not possible to correct the zone recognition in CYPETHERM HE.

Missing walls in the corresponding thermal zone. Gaps in the surfaces of the thermal envelope. The roof was divided into many parts, although it had the same construction system. Some constructive systems did not have any building surface assigned.

It is not possible to correct the building geometry in CYPETHERM HE.

The name of the constructive system was imported correctly, but none of the materials could be imported from Revit.

Create the typologies in CYPETHERM HE.

None of the materials could be imported from Revit.

Create the typologies in CYPETHERM HE.

None of the materials could be imported from Revit.

Create the typologies in CYPETHERM HE.

\subsection{Evaluation of the Processes}

As this article aims to evaluate the interoperability of BIM to BEM, all the processes are summarized in Table 4, in order to determine which one is the most feasible to implement in a daily office routine, under the vision of an architect user of the softwares. The feasibility was analysed according to the time spent, the effort dedicated, and the difficulty presented in each process, rated on a scale from 1 to 5 , where 1 represents the easiest process and 5 represents the most difficult. This analysis was made according to a generic model which had a complexity level similar to that of the warehouse case.

As can be seen from Table 4, exporting to the gbXML file was considered easier than the IFC format. At the moment of exporting the IFC from Revit, some specific parameters must be set correctly; otherwise, it cannot extract the data properly.

Table 4. Comparative table with assessment of the processes. Scale range: 1 to 5 , where 1 means the most feasible.

\begin{tabular}{|c|c|c|c|c|c|}
\hline \multirow{3}{*}{ Process } & \multirow{2}{*}{\multicolumn{2}{|c|}{$\begin{array}{c}\text { Export } \\
\text { Revit }\end{array}$}} & \multirow{3}{*}{$\begin{array}{l}\text { Design Builder } \\
\text { gbXML }\end{array}$} & \multirow{3}{*}{$\begin{array}{c}\text { Import } \\
\text { Open Studio } \\
\text { gbXML }\end{array}$} & \multirow{3}{*}{$\begin{array}{l}\text { CYPETHERM HE } \\
\text { IFC }\end{array}$} \\
\hline & & & & & \\
\hline & gbXML & IFC & & & \\
\hline Export/Import the files & 3 & 3 & 1 & 1 & 1 \\
\hline Verify the information transferred & - & - & 4 & 4 & 3 \\
\hline Correct the dimension errors & - & - & 3 & 5 & 5 \\
\hline Correct the geometry errors & - & - & 3 & 5 & 5 \\
\hline Correct the material errors & - & - & 3 & 3 & 2 \\
\hline Total & 3 & 3 & 14 & 18 & 16 \\
\hline
\end{tabular}


In turn, in the BEM softwares, importing the gbXML and IFC did not present any difficulty, as long as the interface at the time of import was correctly defined in the energy tool. The interoperability in Design Builder was considered the most feasible one and that in Open Studio was the least viable.

\subsection{Simulation Results}

After analyzing the import of the gbXML and IFC files of the residential building and the warehouse into BEM software, all the models were simulated with the aim of assessing whether the energy results would differ, with respect to the BEM software used. The simulations were executed monthly, from 1st January to 31st December, using the weather file of Madrid, Spain, under ideal loads.

However, among the three processes carried out, only the first and the third related to the residential case presented results. The gbXML file of the house imported in Open Studio showed some fatal errors in its geometry (e.g., missing walls and floors), which made its energy calculation impossible. Furthermore, the warehouse case was not simulated. Its gbXML and IFC files were imported in BEM tools without any problem; however, the model was not constructed properly. Missing elements and gaps in the thermal envelope, such as in the roof and external walls, were among the fatal errors encountered.

Therefore, only the results of the first and the third processes (see Figure 1) of the residential case were analysed:

1. gbXML file exported from Revit and imported in Design Builder.

2. IFC file exported from Revit and imported in CYPETHERM HE.

As this research intends to verify the interoperability between the data transfer from BIM to BEM, at the moment of comparing the results, two constructive elements were selected that can be inserted and modified in BIM and are essential to the study of energy modelling: the windows and the opaque envelope.

- Windows Heat Gain

As can be seen in Figure 10, there was a big difference between the model results of the residential case. First of all, the windows heat addition value of the first process was six times smaller than the third case, simulated in CYPETHERM HE. Once the huge discrepancy among these values was determined, we intended to discover where the problem originated from and, so, we collected the information about three parameters that could have influenced the window heat addition: Area of multiplied openings $\left(\mathrm{m}^{2}\right)$, glass U-factor, and glass SHGC (Table 5).

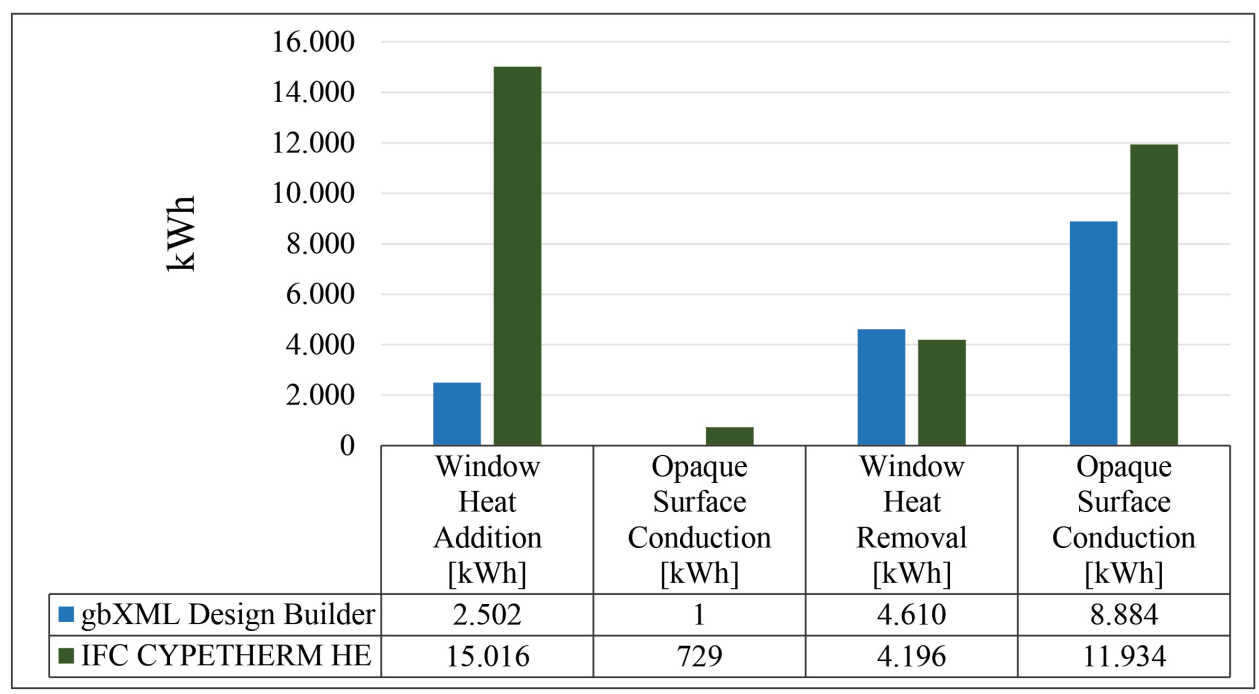

Figure 10. Heat gain components of the residential building simulations. 
Table 5. Window properties.

\begin{tabular}{|c|c|c|c|c|c|}
\hline & $\begin{array}{l}\text { Windows Heat } \\
\text { Addition }\end{array}$ & $\begin{array}{c}\text { Area of } \\
\text { Openings }\left[\mathrm{m}^{2}\right]\end{array}$ & $\begin{array}{c}\text { Glass } \\
\text { U-Factor }\left[\mathrm{W} / \mathrm{m}^{2} \mathrm{~K}\right]\end{array}$ & $\begin{array}{l}\text { Glass } \\
\text { SHGC }\end{array}$ & $\begin{array}{c}\text { Windows } \\
\text { Frame }\left[\text { Total } \mathrm{m}^{2}\right]\end{array}$ \\
\hline Revit & - & 39.24 & 3.69 & 0.78 & 6.70 \\
\hline $\begin{array}{l}\text { gbXML in Design } \\
\text { Builder }\end{array}$ & 2501.83 & 38.13 & 2.93 & 0.13 & - \\
\hline $\begin{array}{l}\text { IFC in } \\
\text { CYPETHERM HE }\end{array}$ & $15,015.64$ & 33.00 & 3.68 & 0.70 & - \\
\hline
\end{tabular}

Therefore, we found that, in the gbXML file, the glass U-values and SHGC were not equal to those in Revit (see Table 5). For some reason, the U-value was $2925 \mathrm{~W} / \mathrm{m}^{2} \mathrm{~K}$ and the SHGC was 0.13 , while, in Revit, they were $3.68 \mathrm{~W} / \mathrm{m}^{2} \mathrm{~K}$ and 0.78 , respectively. This was a failure in the transfer of the data from BIM to the gbXML file, which explains the lowest value of window heat addition among the two cases.

On the other hand, the third process, which had the IFC file imported in the CYPETHERM HE software, presented the exact same glass U-value as in Revit. However, at the moment of analysing the IFC file in Notepad, we detected that the glass SHGC was not transferred to the IFC and, therefore, a SHGC default value equal to 0.70 was set automatically in CYPETHERM HE.

Regarding the area of openings, gbXML had a value closer to the BIM. In Revit, the window total was $39.24 \mathrm{~m}^{2}$, while the gbXML and IFC files presented values $3 \%$ and $15 \%$ smaller than BIM, respectively.

Another interoperability problem was related to the window frames. In the BIM model, the openings had wooden frames, but their thermal properties were not defined. This information was not extracted to the gbXML and IFC files and, therefore, none of this opaque fraction of the opening was transferred to the BEM.

- Opaque Surface Conduction

As can be seen from Table 6, there were differences between the areas and U-values of the thermal envelope opaque elements (i.e., floors, walls, and roof).

Table 6. Opaque Surface Conduction Elements.

\begin{tabular}{|c|c|c|c|c|c|c|c|}
\hline & \multirow{2}{*}{$\begin{array}{c}\text { Opaque Surface } \\
\text { Conduction Addition } \\
{[\mathrm{kWh}]}\end{array}$} & \multicolumn{2}{|c|}{ Exterior Wall } & \multicolumn{2}{|c|}{ Ground Floor } & \multicolumn{2}{|c|}{ Sloped Roof } \\
\hline & & $\begin{array}{l}\text { Area } \\
{\left[\mathrm{m}^{2}\right]}\end{array}$ & $\begin{array}{l}\text { U-Factor } \\
{\left[\mathrm{W} / \mathrm{m}^{2} \mathrm{~K}\right]}\end{array}$ & $\begin{array}{l}\text { Area } \\
{\left[\mathrm{m}^{2}\right]}\end{array}$ & $\begin{array}{l}\text { U-Factor } \\
{\left[\mathrm{W} / \mathrm{m}^{2} \mathrm{~K}\right]}\end{array}$ & $\begin{array}{l}\text { Area } \\
{\left[\mathrm{m}^{2}\right]}\end{array}$ & $\begin{array}{l}\text { U-Factor } \\
\left.\text { [W/m } / \mathbf{m}^{2} \mathbf{K}\right]\end{array}$ \\
\hline Revit & - & 309.00 & 0.33 & 113.00 & 3.03 & 98.00 & 0.41 \\
\hline $\begin{array}{l}\text { gbXML in } \\
\text { Design Builder }\end{array}$ & 0.76 & 132.84 & 0.46 & 67.05 & 1.92 & $\begin{array}{c}\text { No } \\
\text { information }\end{array}$ & 0.44 \\
\hline $\begin{array}{l}\text { IFC in } \\
\text { CYPETHERM } \\
\text { HE }\end{array}$ & 728.50 & 243.05 & 0.37 & $\begin{array}{c}\text { No } \\
\text { information }\end{array}$ & 0.61 & 84.40 & 0.36 \\
\hline
\end{tabular}

The gbXML presented the lowest value for the exterior walls: $132.84 \mathrm{~m}^{2}, 57 \%$ less than the area in the BIM $\left(309.00 \mathrm{~m}^{2}\right)$. In addition, the IFC also showed a small value, but only $21 \%$ less. Moreover, the U-factor in the first process was 39\% bigger than in the BIM model baseline, which was inconsistent as, in Design Builder, a template was created with all Revit materials imported. Consequently, the material properties should have been the same.

In relation to the ground floor, clearly there were issues regarding the recognition of the imported data. First of all, in the simulation of the third case, there was no information about the area of this floor, and its U-value was much lower than in the BIM (by 80\%). Moreover, the gbXML also showed differences with Revit, as its surface area was $40.67 \%$ smaller and its U-factor was $36.63 \%$ lower.

Finally, referring to the sloped roof, the U-factor values did not differ much from the baseline model. However, in the first simulation process, any information about the roof area was extracted and, in the IFC, there was a difference of $-13.87 \%$. 
These differences between BIM and BEM must be taken into account, as they are relevant to the energy analysis. In addition, in a smaller scale building, it is easier to correct the differences in the thermal properties of the envelope materials. However, when it comes to a bigger building, the work required to correct them would take a long time and would be prone to human error, by missing some property that was transferred incorrectly. Therefore, it is crucial that these values are either the same as in the BIM authoring tool, or present very small differences that can be disregarded.

\section{Conclusions}

The lack of BIM-BEM interoperability is one of the existing gaps between digitalisation and the construction area. As BEMs are the basis of energy performance certificates (EPCs), they should present accurate results, in order to guarantee the confidence of investors in the energy efficiency sector.

It was observed that there exists a semi-automated workflow between BIM and BEM. First of all, at the moment of exporting the gbXML and IFC files, some parameters must be activated in Revit. Secondly, it is necessary to set the BEM tool appropriately for the model schema data import, with respect to the building typology, ideal loads, occupation schedule, and weather file.

However, their configuration was not sufficient to ensure adequate interoperability, as many of the problems encountered in the BEM softwares were consequences of errors from transfer of the BIM authoring tool data to gbXML and IFC files. Neither the energy models created with gbXML nor IFC can be trusted as a reference for the BIM, as they presented thermal properties and geometry values different from the baseline model, which led to distinctive and erroneous simulation results.

In addition, the BIM-BEM interoperability does not work for all types of buildings. It was shown that the bigger and more complex the building is (related to its shape and constructive systems), the less reliable the data transferred is and, so, the greater the problems in creating the model in the BEM software. These geometry issues resulted in fatal errors and made the energy simulations impossible.

In summary, BIM-BEM interoperability still has many shortcomings. We generated simulation results for the residential building, but they were not reliable. On the other hand, the warehouse could not even be simulated. For these reasons, it is possible to conclude that greater confidence can be had when recreating the model in a native BEM tool, in order to guarantee the better quality of results without geometric or construction component errors. Therefore, it is understood that the BIM to BEM interoperability is not ready to save time and costs in the design process, under the current state-of-the-art. A bigger effort should be made by standardization bodies, in order to increase the confidence of stakeholders.

Author Contributions: conceptualization, G.B.P., C.F.B., K.D.V.d.L. and A.S.-O.G.; methodology, G.B.P., C.F.B., K.D.V.d.L. and A.S.-O.G.; software, G.B.P. and K.D.V.d.L.; validation, G.B.P., C.F.B. and K.D.V.d.L.; investigation, G.B.P. and K.D.V.d.L.; resources, C.F.B.; writing—original draft preparation, G.B.P.; writing—review and editing, G.B.P., C.F.B., K.D.V.d.L. and A.S.-O.G.; supervision, C.F.B. and A.S.-O.G.; project administration, C.F.B.; funding acquisition, C.F.B. All authors have read and agreed to the published version of the manuscript.

Funding: This research was funded by the Government of Navarra (Spain) under the project "From BIM to BEM: B\&B" (ref. 0011-1365-2020-000227).

Institutional Review Board Statement: Not applicable.

Informed Consent Statement: Not applicable.

Data Availability Statement: Not applicable.

Acknowledgments: We would like to thank Fundación Saltoki for making its warehouse BIM model available, which served as a case study for this research. We also thank CYPE Ingenieros for their support and collaboration during this study. 
Conflicts of Interest: The authors declare no conflict of interest.

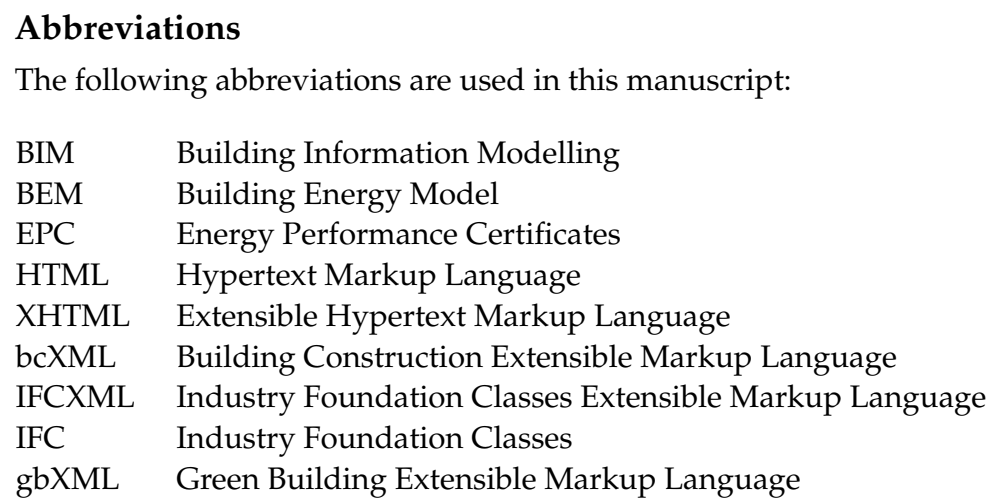

\section{References}

1. Ruiz, G.R.; Bandera, C.F.; Temes, T.G.A.; Gutierrez, A.S.O. Genetic algorithm for building envelope calibration. Appl. Energy 2016, 168, 691-705. [CrossRef]

2. Hogeling, J.; Derjanecz, A. The 2nd recast of the Energy Performance of Buildings Directive (EPBD). Eu Policy News Rehva J. 2018, 55, 71-72.

3. Parliament, E. Directive 2018/844 of the European Parliament and of the Council of 30 May 2018 amending Directive 2010/31/EU on the energy performance of buildings and Directive 2012/27/EU on energy efficiency. Off. J. Eur. Union 2018, 156, 75-91.

4. Li, Y.; Kubicki, S.; Guerriero, A.; Rezgui, Y. Review of building energy performance certification schemes towards future improvement. Renew. Sustain. Energy Rev. 2019, 113, 109244. [CrossRef]

5. Asdrubali, F.; Baggio, P.; Prada, A.; Grazieschi, G.; Guattari, C. Dynamic life cycle assessment modelling of a NZEB building. Energy 2020, 191, 116489. [CrossRef]

6. González, V.G.; Ruiz, G.R.; Segarra, E.L.; Gordillo, G.C.; Bandera, C.F. Characterization of building foundation in building energy models. In Proceedings of the Building Simulation, Rome, Italy, 2-4 September 2019.

7. Elagiry, M.; Dugue, A.; Costa, A.; Decorme, R. Digitalization Tools for Energy-Efficient Renovations. Proceedings 2020, 65, 5009. [CrossRef]

8. Elagiry, M.; Marino, V.; Lasarte, N.; Elguezabal, P.; Messervey, T. BIM4Ren: Barriers to BIM implementation in renovation processes in the Italian market. Buildings 2019, 9, 200. [CrossRef]

9. Bergonzoni, G.; Marino, V.; Elagiry, M.; Costa, A. Assessing Residential Buildings Compliance with Sustainability Rating Systems through a BIM-Based Approach. Proceedings 2021, 65, 22. [CrossRef]

10. Ullah, K.; Lill, I.; Witt, E. An overview of BIM adoption in the construction industry: Benefits and barriers. In Proceedings of the 10th Nordic Conference on Construction Economics and Organization, Tallinn, Estonia, 7-8 May 2019; Emerald Publishing Limited: Bingley, UK, 2019.

11. Maskuriy, R.; Selamat, A.; Ali, K.N.; Maresova, P.; Krejcar, O. Industry 4.0 for the construction industry how ready is the industry? Appl. Sci. 2019, 9, 2819. [CrossRef]

12. de Lange, P.; Bähre, B.; Finetti-Imhof, C.; Klamma, R.; Koch, A.; Oppermann, L. Socio-technical Challenges in the Digital Gap between Building Information Modeling and Industry 4.0. In Proceedings of the 3rd International Workshop on Socio-Technical Perspective in IS Development (STPIS@ CAiSE), Essen, Germany, 13 June 2017, pp. 33-46.

13. González, V.G.; Colmenares, L.Á.; Fidalgo, J.F.L.; Ruiz, G.R.; Bandera, C.F. Uncertainy's Indices Assessment for Calibrated Energy Models. Energies 2019, 12, 2096. [CrossRef]

14. Fernández Bandera, C.; Ramos Ruiz, G. Towards a new generation of building envelope calibration. Energies 2017, 10, 2102. [CrossRef]

15. Dodier, R.H.; Henze, G.P. Statistical analysis of neural networks as applied to building energy prediction. J. Sol. Energy Eng. 2004, 126, 592-600. [CrossRef]

16. Reynders, G.; Diriken, J.; Saelens, D. Quality of grey-box models and identified parameters as function of the accuracy of input and observation signals. Energy Build. 2014, 82, 263-274. [CrossRef]

17. Ramos Ruiz, G.; Lucas Segarra, E.; Fernández Bandera, C. Model predictive control optimization via genetic algorithm using a detailed building energy model. Energies 2019, 12, 34. [CrossRef]

18. Gutiérrez González, V.; Ramos Ruiz, G.; Fernández Bandera, C. Empirical and Comparative Validation for a Building Energy Model Calibration Methodology. Sensors 2020, 20, 5003. [CrossRef]

19. Choi, J.; Shin, J.; Kim, M.; Kim, I. Development of openBIM-based energy analysis software to improve the interoperability of energy performance assessment. Autom. Constr. 2016, 72, 52-64. [CrossRef]

20. Abanda, F.; Byers, L. An investigation of the impact of building orientation on energy consumption in a domestic building using emerging BIM (Building Information Modelling). Energy 2016, 97, 517-527. [CrossRef] 
21. Segarra, E.L.; Ruiz, G.R.; González, V.G.; Peppas, A.; Bandera, C.F. Impact Assessment for Building Energy Models Using Observed vs. Third-Party Weather Data Sets. Sustainability 2020, 12, 6788. [CrossRef]

22. Pezeshki, Z.; Soleimani, A.; Darabi, A. Application of BEM and using BIM database for BEM: A review. J. Build. Eng. 2019, 23, 1-17. [CrossRef]

23. Spiridigliozzi, G.; Pompei, L.; Cornaro, C.; De Santoli, L.; Bisegna, F. BIM-BEM support tools for early stages of zero-energy building design. Iop Conf. Ser. Mater. Sci. Eng. 2019, 609, 072075. [CrossRef]

24. Farzaneh, A.; Monfet, D.; Forgues, D. Review of using Building Information Modeling for building energy modeling during the design process. J. Build. Eng. 2019, 23, 127-135. [CrossRef]

25. Aranda, J.; Martin-Dorta, N.; Naya, F.; Conesa-Pastor, J.; Contero, M. Sustainability and Interoperability: An Economic Study on BIM Implementation by a Small Civil Engineering Firm. Sustainability 2020, 12. [CrossRef]

26. Pinheiro, S.; Wimmer, R.; O'onnell, J.; Muhic, S.; Bazjanac, V.; Maile, T.; Frisch, J.; van Treeck, C. MVD based information exchange between BIM and building energy performance simulation. Autom. Constr. 2018, 90, 91-103. [CrossRef]

27. Gerrish, T.; Ruikar, K.; Cook, M.; Johnson, M.; Phillip, M. Using BIM capabilities to improve existing building energy modelling practices. Eng. Constr. Archit. Manag. 2017. [CrossRef]

28. Hijazi, M.; Kensek, K.; Konis, K. Bridging the gap: Supporting data transparency from BIM to BEM. Archit. Res. $2015,150$.

29. Sanhudo, L.; Ramos, N.M.; Martins, J.P.; Almeida, R.M.; Barreira, E.; Simões, M.L.; Cardoso, V. Building information modeling for energy retrofitting-A review. Renew. Sustain. Energy Rev. 2018, 89, 249-260. [CrossRef]

30. Kamel, E.; Memari, A.M. Review of BIM's application in energy simulation: Tools, issues, and solutions. Autom. Constr. 2019, 97, 164-180. [CrossRef]

31. Akbarieh, A. Systematic Investigation of Interoperability Issues between Building Information Modelling and Building Energy Modelling-BIM-Based BEM Information Exchange Issues. Master's Thesis, NTNU, Taipei, Taiwan, 2018.

32. Dimitriou, V.; Firth, S.K.; Hassan, T.M.; Fouchal, F. BIM enabled building energy modelling: Development and verification of a GBXML to IDF conversion method. In Proceedings of the 3rd IBPSA-England Conference BSO, Great North Museum, Newcastle, 12-14 September 2016; p. 1126.

33. Wetter, M.; van Treeck, C.; Helsen, L.; Maccarini, A.; Saelens, D.; Robinson, D.; Schweiger, G. IBPSA Project 1: BIM/GIS and Modelica framework for building and community energy system design and operation-ongoing developments, lessons learned and challenges. In Proceedings of the IOP Conference Series: Earth and Environmental Science, Graz, Austria, 11-14 September 2019; IOP Publishing: Bristol, UK, 2019; Volume 323, p. 012114.

34. Elagiry, M.; Charbel, N.; Bourreau, P.; Di Angelis, E.; Costa, A. IFC to Building Energy Performance Simulation: A Systematic Review of the Main Adopted Tools and Approaches. In Proceedings of the BauSIM 2020-8th Conference of IBPSA Germany and AustriaAt, Graz University of Technology, Graz, Austria, 23-25 September 2020.

35. Gumbarević, S.; Burcar Dunović, I.; Milovanović, B.; Gaši, M. Method for Building Information Modeling Supported Project Control of Nearly Zero-Energy Building Delivery. Energies 2020, 13, 5519. [CrossRef]

36. Gao, H.; Koch, C.; Wu, Y. Building information modelling based building energy modelling: A review. Appl. Energy 2019, 238, 320-343. [CrossRef]

37. Osello, A.; Cangialosi, G.; Dalmasso, D.; Di Paolo, A.; Turco, M.L.; Piumatti, P.; Vozzola, M. Architecture data and energy efficiency simulations: BIM and interoperability standards. In Proceedings of the Building Simulation, Sydney, Australia, 14-16 November 2011.

38. Crawley, D.B.; Lawrie, L.K.; Winkelmann, F.C.; Buhl, W.F.; Huang, Y.J.; Pedersen, C.O.; Strand, R.K.; Liesen, R.J.; Fisher, D.E.; Witte, M.J.; et al. EnergyPlus: Creating a new-generation building energy simulation program. Energy Build. 2001, 33, 319-331. [CrossRef]

39. Zhang, L. Simulation analysis of built environment based on design builder software. Appl. Mech. Mater. Trans. Tech. Publ. 2014, 580, 3134-3137. [CrossRef]

40. Guglielmetti, R.; Macumber, D.; Long, N. OpenStudio: An Open Source Integrated Analysis Platform; Technical Report; National Renewable Energy Lab. (NREL): Golden, CO, USA, 2011.

41. Ingenieros, C. Software Para Ingenieria, Arquitectura y Construccion. Available online: http://www.cype.es (accessed on 31 January 2021).

42. van Treeck, C.; Wimmer, R.; Maile, T. BIM for energy analysis. In Building Information Modeling; Springer: Berlin/Heidelberg, Germany, 2018; pp. 337-347.

43. Alsharif, R. A Review on the Challenges of BIM-Based BEM Automated Application in AEC Industry. 2019. Available online: https://www.researchgate.net/publication/337888446_A_review_on_the_challenges_of_BIM-based_BEM_automated_ application_in_AEC_industry (accessed on 12 February 2021).

44. Moretti, N.; Xie, X.; Merino, J.; Brazauskas, J.; Parlikad, A.K. An openBIM Approach to IoT Integration with Incomplete As-Built Data. Appl. Sci. 2020, 10, 8287. [CrossRef] 